Brit. Heart F., 1966, 28, 698.

\title{
Excretion of Urocanic Acid Following Oral Histidine in Heart Failure
}

\author{
J. J. DALY AND D. P. ROSE \\ From the Department of Medicine, and the Department of Chemical Pathology, University of Sheffeld
}

\begin{abstract}
Abnormalities of hepatic excretory function occur in patients with congestive cardiac failure and tend to improve with recovery (Sherlock, 1951; Evans et al., 1952). In liver disease or folic acid deficiency, abnormal quantities of the metabolites, urocanic acid and formiminoglutamic acid (Figlu), appear in the urine following an oral dose of the amino acid L-histidine (Luhby, Cooperman, and Teller, 1959; Spray and Witts, 1959; Kohn, Mollin, and Rosenbach, 1961; Carter, Schaffner, and Heller, 1960; Bennett and Chanarin, 1962; Merritt et al., 1962). In mammalian liver, the major pathway of histidine metabolism is its degradative conversion via urocanic acid to glutamic acid (Fig. 1). The abnormal excretion of Figlu in heart failure (Gräsbeck, Björkstén, and Nyberg, 1961) was confirmed by one of us (Rose, 1964), and in addition excess urocanic acid was noted. It therefore appeared that the hepatic congestion of heart failure resulted in defective histidine metabolism, and it was decided to study this in more detail. We have therefore estimated the excretion of urocanic acid following an oral dose of histidine in patients with congestive cardiac failure due to cor pulmonale or rheumatic heart disease. These patients had no evidence of malnutrition, cirrhosis of the liver, or anæmia.
\end{abstract}

\section{SUBJECTS AND METHODS}

Studies were made on 8 women and 11 men aged between 30 and 72, and details are given in Table I. Twelve patients were suffering from cor pulmonale due to chronic bronchitis and emphysema, 6 had rheumatic disease, and 1 had constrictive pericarditis. Of the 12 patients with cor pulmonale, 5 had improved considerably at the time of study and had minimal or virtually no œdema.

Received December 24, 1965.
Patients were studied in the fasting state and as far as possible blood and urine samples were collected on the same day. Blood was sampled from a brachial artery via an indwelling needle. Arterial oxygen saturation $\left(\mathrm{SaO}_{2}\right)$ was measured by a spectrophotometric method (Verel, Saynor, and Kesteven, 1960), pH was measured using a glass electrode and an E.I.L. $p \mathrm{H}$ meter. Blood bicarbonate was obtained by the method of Van Slyke and Neill (1924). Arterial $\mathrm{PcO}_{2}\left(\mathrm{~Pa}_{\mathrm{cO} 2}\right)$ was obtained from $p \mathrm{H}$ and bicarbonate values using the nomogram of Singer and Hastings (1948).

Urine was collected for a period of 8 hours immediately following the oral administration of $15 \mathrm{~g}$. of L-histidine. Previous studies had shown that the increased excretion of histidine metabolites following an oral load of the amino acid was practically complete within 8 hours, both in the normal subject and in patients with impaired hepatic function (Rose, 1964).

Estimation of Urocanic Acid. The method used for the present study has been described in detail elsewhere (Rose, 1964). Two-dimensional paper chromatography (n-butanol, acetic acid, water, 12:5:3 for the first solvent, followed by n-butanol, pyridine, water, $1: 1: 1$ ) was carried out on desalted concentrates of urine. The spots of urocanic acid were located by their fluorescence in ultraviolet light and were cut from the papers. The urocanic acid was eluted into a mixture of tert-butyl alcohol, distilled water, and 10 per cent sodium carbonate solution (5:5:1), and the absorbency of colour developed with diazotized sulphanilic acid was read with a "Uvispek" spectrophotometer at a wavelength of $500 \mathrm{~m} \mu$. Standard solutions were applied to separate papers to give 10 and $20 \mu \mathrm{g}$. of urocanic acid on the chromatograms and were carried through the whole procedure. The relation between absorbency and amount of urocanic acid applied to chromatograms was linear over a range $0-20 \mu \mathrm{g}$. Recoveries of pure standards added to urine were in the region of $85-90$ per cent.

Urocanic acid excretion was measured by this method in 8 healthy subjects and in 7 patients in whom there was no evidence of liver disease or heart failure. Results are 698 
<smiles>NC(=O)Cc1cnc[nH]1</smiles>

L- HISTIDINE<smiles>O=CN=CNCCCCC(=O)O</smiles>

TRANS-UROCANIC<smiles>O=C(O)CC[C@@H]1NC=N[C@H]1O</smiles>

IMIDAZOLONEPROPIONIC ACID

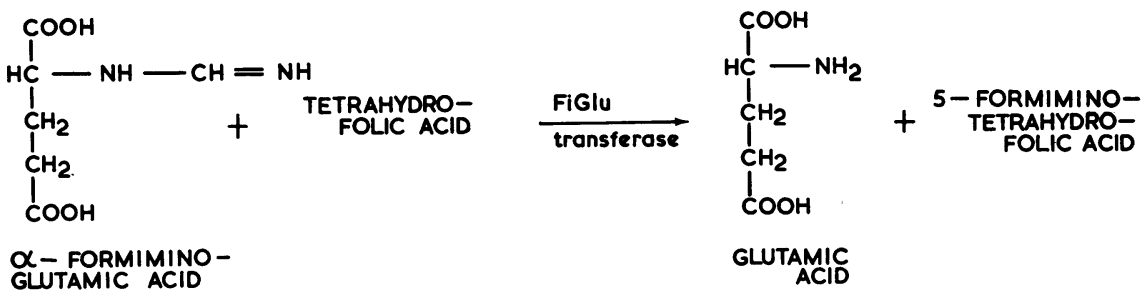

FIG. 1.-The "histidine-glutamic acid" pathway.

in the 8-hour period following $15 \mathrm{~g}$. oral histidine was 0-2 mg./hr. Comparison of the results with those of previous workers is difficult because of differing histidine dose, and varying periods of urine collection. However, in view of the finding that most of the urocanic acid is excreted in the first 8 hours after a $15 \mathrm{~g}$. histidine load, the differences introduced by using this period of collection rather than a longer one should be small. The range of excretion of urocanic acid in normal subjects obtained by the present method is of the same general order as that found by previous workers.

Estimation of Figlu. Urinary excretion of Figlu was estimated in 8 patients using cellulose acetate electrophoresis, as previously described (Kohn et al., 1961). Normal values are approximately $0-2 \mathrm{mg}$. $/ \mathrm{hr}$. Because the method is only semiquantitative, results are expressed as, normal (0), slight excess $(+)$, moderate $(++)$, or notable excess $(+++)$. These correspond to the ranges less than $2 \mathrm{mg}$./hr., 2-10 mg./hr., 10-20 mg./hr., and above $20 \mathrm{mg} . / \mathrm{hr}$.

Serum Transaminases. The expression of activity used by King (1958) for the serum glutamic oxalacetic transaminase (SGOT) and serum glutamic pyruvic transaminase (SGPT) is such that the upper limit of normal for both enzymes is 100 King units.

\section{RESULTS}

Table I gives the values for urocanic acid excretion, $\mathrm{SaO}_{2}$, and $\mathrm{Pa}_{\mathrm{CO} 2}$. Urocanic acid values

TABLE I

UROCANIC ACID EXCRETION, SaO2, AND PaCo2 IN 19 PATIENTS WITH HEART FAILURE

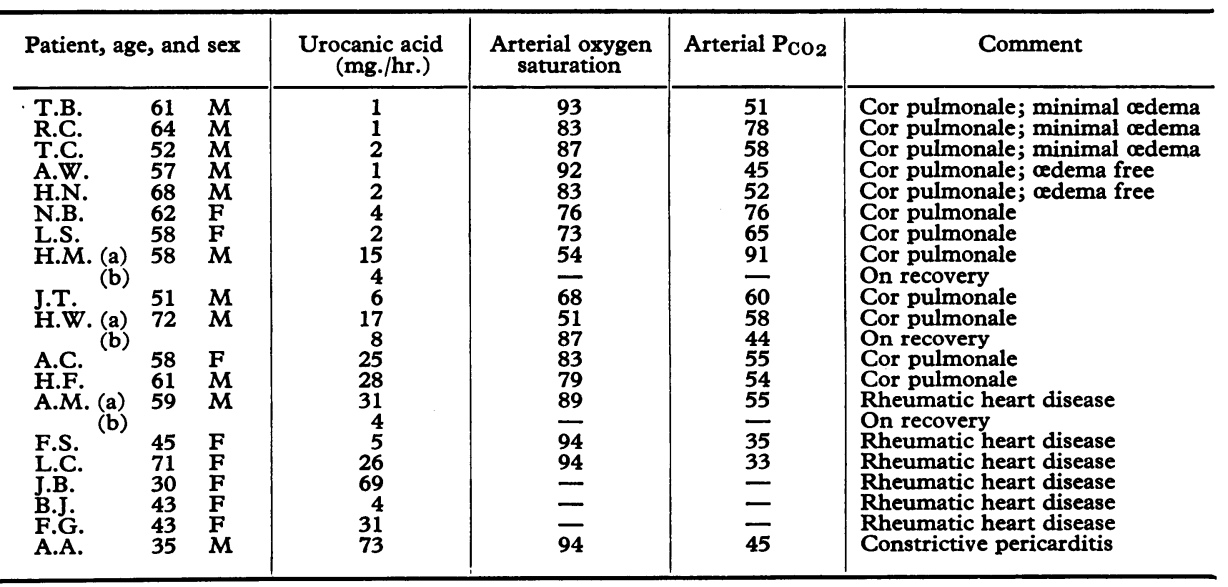


were above the normal range in 15 of the 19 patients, being $2-73 \mathrm{mg}$. $/ \mathrm{hr}$. The excretion of urocanic acid in 6 patients with rheumatic heart disease was 14-69 mg./hr. with a mean of $28 \mathrm{mg}$. $/ \mathrm{hr}$., and the blood gases were abnormal in 1 of the 3 patients in this group in whom they were estimated. Urocanic acid excretion range in the pulmonary heart failure group was 1-28 mg./hr. with a mean of $9 \mathrm{mg}$., and $\mathrm{SaO}_{2}$ ranged from 51 per cent to 93 per cent with an average value of 77 per cent. Corresponding values for $\mathrm{Pa}_{\mathrm{CO} 2}$ were $45-91 \mathrm{~mm} . \mathrm{Hg}$ and $62 \mathrm{~mm} . \mathrm{Hg}$. The 4 patients with normal urocanic acid excretion had almost recovered from heart failure; 2 were œdema free and 2 had minimal congestion. There was a correlation between urocanic acid excretion and the degree of hypoxia in the 12 patients with cor pulmonale $(\mathrm{r}=0.53 ; \mathrm{t}=<0.05) \quad$ (Fig. 2$)$. The remaining patient with constrictive pericarditis had

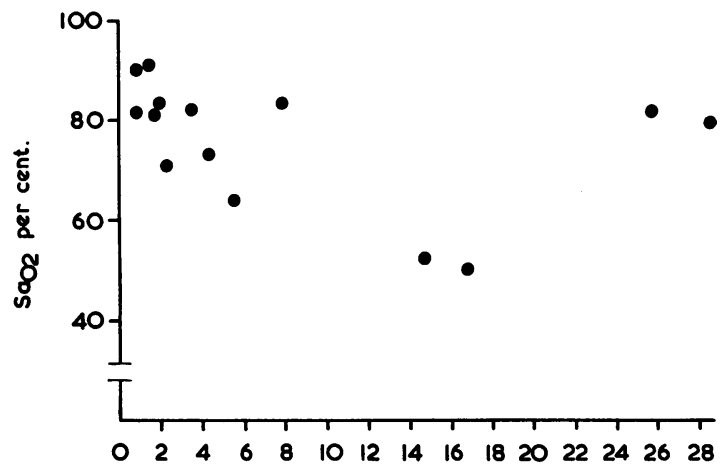

U.A. mg. per hour

FIG. 2.-Urocanic acid (UA) excretion values plotted against arterial oxygen saturation $\left(\mathrm{Sa}_{\mathrm{O}_{2}}\right)$ in 12 patients with cor pulmonale $(r=0.53$. $t=<0.05)$.

normal blood gases and the highest value for urocanic acid excretion in the series (73 mg./hr.). In 2 patients with pulmonary heart disease and 1 with rheumatic heart disease the urocanic acid excretion following recovery from heart failure had decreased considerably but not to normal values (Table I). In 1 of these patients (A.M.) with rheumatic heart disease, who subsequently relapsed and died, the liver showed no histological evidence of cirrhosis.

The results of Figlu determinations are included in Table III, with corresponding values for urocanic acid excretion, in 3 patients with cor pulmonale and 4 with rheumatic heart disease. Figlu excretion was normal or slightly raised in patients with cor pulmonale, in the presence of raised urocanic acid levels. Of the 4 patients with rheumatic heart disease, 3 had moderate to marked increases in Figlu and urocanic acid excretion.
TABLE II

URINARY EXCRETION OF UROCANIC ACID IN 8 HEALTHY SUBJECTS AND 7 PATIENTS FOLLOWING AN ORAL DOSE OF HISTIDINE

\begin{tabular}{|c|c|c|c|c|}
\hline \multicolumn{3}{|c|}{$\begin{array}{l}\text { Subject, sex, } \\
\text { and age }\end{array}$} & Diagnosis & $\begin{array}{c}\begin{array}{c}\text { Urocanic } \\
\text { acid } \\
\text { excretion } \\
\text { (mg./hr.) }\end{array} \\
0\end{array}$ \\
\hline $\begin{array}{r}1 \\
2 \\
3 \\
4 \\
5 \\
6 \\
7 \\
8 \\
9 \\
10 \\
11 \\
12 \\
13 \\
14 \\
15\end{array}$ & $\begin{array}{l}\mathrm{M} \\
\mathrm{F} \\
\mathrm{F} \\
\mathrm{M} \\
\mathrm{M} \\
\mathrm{M} \\
\mathrm{M} \\
\mathrm{M} \\
\mathrm{M} \\
\mathrm{M} \\
\mathrm{F} \\
\mathrm{F} \\
\mathrm{M} \\
\mathrm{F}\end{array}$ & $\begin{array}{l}23 \\
27 \\
34 \\
26 \\
27 \\
77 \\
59 \\
26 \\
24 \\
26 \\
65 \\
66 \\
48 \\
45 \\
51\end{array}$ & $\begin{array}{l}\text { Healthy } \\
\text { Healthy } \\
\text { Healthy } \\
\text { Healthy } \\
\text { Healthy } \\
\text { Convalescent pneumonia } \\
\text { Venous thrombosis of leg } \\
\text { Healthy } \\
\text { Healthy } \\
\text { Healthy } \\
\text { Cataract, retinal hæmorrhage } \\
\text { Myocardial infarct } \\
\text { Diabetes mellitus } \\
\text { Epilepsy }\end{array}$ & $\begin{array}{l}0 \\
1 \\
1 \\
1 \\
1 \\
1 \\
2 \\
2 \\
1 \\
1 \\
1 \\
1 \\
2 \\
2 \\
2\end{array}$ \\
\hline
\end{tabular}

TABLE III

FIGLU AND CORRESPONDING UROCANIC ACID EXCRETION RATES IN PATIENTS WITH PULMONARY OR RHEUMATIC HEART FAILURE; 1 PATIENT WITH CONSTRICTIVE PERICARDITIS'IS ALSO INCLUDED

\begin{tabular}{c|c|c}
\hline Patient & Figlu (mg./hr.) & $\begin{array}{c}\text { Urocanic acid excretion } \\
\text { (mg./hr.) }\end{array}$ \\
\hline Cor Pulmonale & + & 8 \\
H.W. & + & 28 \\
H.F. & 0 & 25 \\
A.C. & & \\
Rheumatic Heart Disease & & \\
J.B. & ++ & 69 \\
B.J. & ++ & 4 \\
F.G. & +++ & 31 \\
A.M. & & 31 \\
Constrictive Pericarditis & \\
A.A. & +++ & 73 \\
\hline
\end{tabular}

TABLE IV

SGOT, SGPT, AND BLOOD UREA IN PATIENTS WITH COR'PULMONALE OR RHEUMATIC HEART FAILURE

\begin{tabular}{l|r|r|c}
\hline Patient & SGOT & SGPT & Blood urea (mg./100 ml.) \\
\hline T.B. & 55 & 25 & 22 \\
R.C. & 90 & 90 & 36 \\
T.C. & 115 & 65 & 20 \\
A.W. & 115 & 125 & 22 \\
H.N. & 45 & 35 & 45 \\
N.B. & 60 & 35 & 32 \\
L.S. & 115 & 90 & 30 \\
H.M. (a) & 230 & 65 & 60 \\
J.T. (b) & 90 & 68 & 42 \\
H.W. & 65 & 65 & 24 \\
A.C. & 120 & 65 & 20 \\
H.F. & 170 & 285 & 52 \\
A.M. (a) & 175 & 70 & 28 \\
F.S. (b) & 1150 & 55 & 38 \\
L.C. & 50 & 15 & 24 \\
J.B. & $=$ & $=$ & 24 \\
B.J. & $=$ & $=$ & 46 \\
F.G. & - & - & 28 \\
A.A. & &
\end{tabular}


Table IV gives the results of serum transaminases and blood urea estimations. SGOT was above 100 units in 5 patients and SGPT above 100 units in 1 patient with cor pulmonale. Blood urea was greater than $45 \mathrm{mg} . / 100 \mathrm{ml}$. in 2 patients, one of whom had the highest SGOT. SGOT and SGPT were greater than 100 in 1 out of 3 patients with rheumatic heart disease. Blood urea was above $45 \mathrm{mg} . / 100 \mathrm{ml}$. in 2 patients. In 2 patients, 1 in each group, SGOT levels decreased on recovery. There was no correlation between serum transaminase activity and the urocanic acid excretion $(r=0 \cdot 18)$.

\section{Discussion}

Congestive cardiac failure may be associated with gastro-intestinal abnormalities, such as proteinlosing enteropathy or slow transit time. Gräsbeck et al. (1961) reported excess Figlu following histidine in 5 patients with heart failure, and demonstrated a decrease in excretion following folic acid therapy. None of the present series suffered from malnutrition, and folic acid therapy was not given. Urocanic acid excretion decreased to near normal with recovery from heart failure and in the absence of folic acid therapy. Therefore, dietary deficiency or deficiency due to malabsorption is unlikely to be the explanation of the abnormal metabolism of histidine in these patients. Knowles, Shaldon, and Fleming (1963) emphasized the role of secondary folic acid deficiency in patients with liver cirrhosis. The defect of histidine metabolism was not fully corrected in these by giving folic acid. There was no evidence of cirrhosis in any of our patients; in 1, necropsy excluded this possibility. Cardiac cirrhosis is relatively rare and it would be unlikely as the explanation of these findings in all the patients in the present study. Sherlock (1951) pointed out that centrilobular hepatic necrosis was common in heart failure and tended to heal with recovery. The structural liver changes were related to circulatory changes, such as reduced cardiac output, increased venous pressure, and the degree of hypoxia. Following hepatic congestion in the dog, Yates, Urquhart, and Herbst (1958) demonstrated impairment of degradation of adrenocortical hormones by hepatic enzymes. It seems possible, therefore, that reduced activity of the enzymes concerned in histidine breakdown is responsible for the present findings and that, in the absence of folic acid deficiency, the most probable factor is hepatic congestion. Interference with enzyme activity might occur at two sites. Figlu may accumulate as a result of suppression of the transferase enzyme, and would tend to produce a reduction in urocanase activity due to negative feed-back, with a resulting build-up of urocanic acid. This mechanism has been suggested as a possible explanation of the findings in folic acid deficiency (McIsaac and Page, 1961). A second mechanism might be direct suppression of urocanase activity without Figlu accumulation. Merritt et al. (1962) obtained some evidence for this in patients with hepatic cirrhosis, and Whitehead (1964) reported increased urinary urocanic acid with low Figlu levels in children with kwashiorkor, suggesting urocanase deficiency as a possible mechanism.

The factors likely to be responsible for the suggested enzyme impairment are congestion and hypoxia. The inverse correlation between $\mathrm{SaO}_{2}$ and urocanic acid excretion in patients with cor pulmonale lends support to the view that hypoxæmia is a contributing factor. Refsum (1963) reported a close correlation between changes in serum transaminase activity and the severity of arterial hypoxæmia in cor pulmonale. The present results showed no correlation between the serum transaminase levels and the urocanic acid excretion of patients with cor pulmonale. Five patients had a raised SGOT, but in 4 the increase was only a little above normal. It is possible, however, that hypoxia results in a functional impairment of hepatic cell activity, reflected by abnormal histidine metabolism, even in the absence of severe structural cell damage. In such cases the serum transaminase levels may be unaltered.

In patients with rheumatic heart failure urocanic acid excretion was higher than in those with cor pulmonale, and excess Figlu was an almost constant finding. These differences may be due to the more chronic nature of the heart failure in the rheumatic group. However, urocanic acid excretion returned to normal in one of these patients on clinical recovery.

\section{SUMMARY}

Urocanic acid excretion has been estimated in 19 patients with congestive cardiac failure following an oral dose of $15 \mathrm{~g}$. of L-histidine.

Among patients with cor pulmonale, 12 had a mean urocanic excretion of $9 \mathrm{mg}$./hr. (normal range 0-2 mg./hr.). There was a correlation between the degree of hypoxia and urocanic acid excretion. In 3 patients with abnormally raised urocanic acid values, Figlu excretion was normal or only minimally increased. In 2 patients urocanic acid excretion decreased considerably, but not to normal levels, on recovery from heart failure.

In 6 patients with rheumatic heart failure mean urocanic acid excretion was $28 \mathrm{mg}$. $/ \mathrm{hr}$. In 3 patients Figlu excretion was also raised. In 1 
patient Figlu excretion was normal and urocanic acid excretion only minimally increased. With recovery from heart failure urocanic acid excretion decreased to a near normal value in 1 patient.

It is suggested that impairment of hepatic enzyme activity would explain these findings, and that possible causes might be hepatic hypoxia or congestion.

\section{REFERENCES}

Bennett, M. C., and Chanarin, I. (1962). Urinary excretion of urocanic acid and formimino-glutamic acid. Nature (Lond.), 196, 271.

Carter, F. C., Schaffner, G., and Heller, P. (1960). Formiminoglutamic acid (Figlu) excretion in hepatic cirrhosis. Clin. Res., 8, 199.

Evans, J. M., Zimmerman, H. J., Wilmer, J. G., Thomas, L. J., and Ethridge, C. B. (1952). Altered liver function of chronic congestive heart failure. Amer. $\mathcal{F}$. Med., 13, 704.

Gräsbeck, R., Björkstén, F., and Nyberg, W. (1961). Formiminoglutaminsyra $i$ urin vid folsyrabrist. Nord. Med., 66, 1343.

King, J. (1958). Routine methods for the estimation of serum transaminase. f. med. Lab. Technol., 15, 17.

Knowles, J. P., Shaldon, S., and Fleming, A. (1963). Folic acid metabolism in liver disease. Clin. Sci., 24, 39.

Kohn, J., Mollin, D. L., and Rosenbach, L. M. (1961). Conventional voltage electrophoresis for formiminoglutamic-acid determination in folic acid deficiency. F. clin. Path., 14, 345.

Luhby, A. L., Cooperman, J. M., and Teller, D. N. (1959). Histidine metabolic loading test to distinguish folic acid deficiency from vit. $B_{12}$ in megaloblastic anemias. Proc. Soc. exp. Biol. (N.Y.), 101, 35.
McIsaac, W. M., and Page, I. H. (1961). Urocanicaciduria associated with hepatic coma. Nature (Lond.), 190, 347.

Merritt, A. D., Rucknagel, D. L., Silverman, M., and Gardiner, R. C. (1962). Urinary urocanic acid in man: The identification of urocanic acid and the comparative excretions of urocanic acid and $\mathrm{N}$-formiminoglutamic acid after oral histidine in patients with liver disease. f. clin. Invest., 41, 1472.

Refsum, H. E. (1963). Arterial hypoxæmia, serum activities of GO-T, GP-T and LDH, and centrilobular liver cell necrosis in pulmonary insufficiency. Clin. Sci., 25, 369.

Rose, D. P. (1964). The urinary excretion of histidine metabolites in folic acid deficiency and liver disease. M.D. Thesis, University of Sheffield.

Sherlock, S. (1951). The liver in heart failure. Relation of anatomical, functional, and circulatory changes. Brit. Heart F., 13, 273.

Singer, R. B., and Hastings, A. B. (1948). An improved clinical method for the estimation of disturbances of the acid-base balance of human blood. Medicine (Baltimore), 27, 223.

Spray, G. H., and Witts, L. J. (1959). Excretion of formiminoglutamic acid as an index of folic-acid deficiency. Lancet, 2, 702.

Van Slyke, D. D., and Neill, J. M. (1924). The determination of gases in blood and other solutions by vacuum extraction and manometric measurement. $\mathcal{F}$. biol. Chem., 61, 523.

Verel, D., Saynor, R., and Kesteven, A. B. (1960). A spectrophotometric method of estimating blood oxygen using the Unicam SP 600 . F. clin. Path., 13, 361.

Whitehead, R. G. (1964). Amino acid metabolism in kwashiorkor: 1. metabolism of histidine and imidazole derivatives. Clin. Sci., 26, 271.

Yates, F. E., Urquhart, J., and Herbst, A. L. (1958). Impairment of the enzymatic inactivation of adrenal cortical hormones following passive venous congestion of the liver. Amer. F. Physiol., 194, 65. 